\title{
Pengaruh Likuiditas, Leverage, Profitabilitas Dan Ukuran Perusahaan Pada Kelengkapan Pengungkapan Laporan Keuangan Perusahaan Rokok Yang Terdaftar Di Bursa Efek Indonesia.
}

\author{
Mei Gita Risti Mawarni ${ }^{1}$, Rina Fariana ${ }^{2}$ \\ Universitas PGRI Adi Buana Surabaya1,2 \\ meigitarmw@gmail.com
}

\begin{abstract}
ABSTRAK
Maksud peneliti melakukan penelitian ini ialah untuk memahami dan mengkaji apakah ada impresi likuiditas, leverage, profitabilitas, dan ukuran perusahaan terhadap kelengkapan pengungkapan laporan keuangan atas perusahaan rokok yang tertera di BEI tahun 2012-2018. Variabel dalam observasi ini yakni 4 perusahaan rokok. Penjabaran eksplorasi ini menggunakan metode analisis regresi linier berganda. Didapatkan hasil uji-t bahwa nilai sig $X_{1}$ sebanyak 0,646< 0,05 , nilai sig $X_{2}$ sebanyak $0,40<0,05$, nilai sig $X_{3}$ sebanyak $0,000<0,05$ dan nilai sig $X_{4}$ sebanyak $0,000<0,05$. Sedangkan dari uji-F diperoleh nilai Fnitung sebanyak 39,520 Dengan sig sebanyak 0,000, sehingga $0,000<0.05$. dari uraian tersebut menunjukan bahwa leverage, profitabilitas dan ukuran perusahaan berpengaruh signifikan dan likuiditas tidak berpengaruh signifikan terhadap kelengkapan pengungkapan laporan keuangan baik secara parsial dan berpengaruh secara simultan.

Kata kunci: Likuiditas, Leverage, Profitabilitas, Ukuran Perusahaan, Kelengkapan Pengungkapan.

ABSTRACT

The purpose of this research is to discuss and examine whether there is liquidity, leverage, profitability, and company size regarding the completeness of financial statement complaints for cigarette companies listed on the Indonesia Stock Exchange in 2012-2018. The variables in this observation are 4 cigarette companies. This exploration explanation uses the method of multiple linear regression analysis. $T$-test results obtained that the value of sig X1 was $0.646<0.05$, the value of sig X2 was 0.40 $<0.05$, the value of sig $X 3$ was $0,000<0.05$ and the value of sig $X 4$ was $0,000<0.05$. Whereas the $F$ test was rated by the Fcount of 39,520 with sig of 0,000, so 0,000 <0.05 From this description shows that leverage, profitability and company size determine significant and Liquidity is not significant to the completeness of complaints.
\end{abstract}

Keyword: Liquidity, Leverage, Profitability, Company Size, Completeness of Disclosure

\section{PENDAHULUAN}

Kondisi perekonomian sangat mempengaruhi dunia usaha, maka agar mampu bersaing, perusahaan dihadapkan untuk dapat mengungkapkan informasi lebih terbuka. sehingga membantu para pengambil keputusan dalam mencegah keadaan yang semakin berubah. Profesi akuntansi sebagai penyedia data bisnis tidak bisa membebaskan diri dengan perubahan perekonomian ini. 
Semakin berkembang suatu bisnis, maka diperlukannya bahan akuntansi yang jelas untuk kewajiban dan untuk panduan pemungutan ketetapan ekonomi. Dalam keterkaitanya dengan pengujian informasi keuangan untuk penelaah maka perlu mengklasifikasikan sistem pemeriksaan laporan keuangan sebuah instansi dan membantu jasa audit untuk memastikan kelaziman petunjuk keuangan.

Pengungkapan laporan keuangan merupakan hal yang sangat mempengaruhi dunia pasar modal. karena merupakan bagian penting dalam pencapaian ketepatan pasar modal dan mengambarkan instrumen akuntabilitas publik. Aspek pergantian sosial bangsa Indonesia mengupayakan dibuatnya hakikat Good Corporate Governance untuk para pemilik bidang usaha menjalankan tema ini sehingga berguna untuk diamati. Poin pentingnya yakni transparansi, tanggung jawab, keadilan, dan akuntanbilitas. Laporan keuangan menjadi kunci para eksekutif untuk mempelihatkan suatu tingkat pencapaian sasaran dan untuk menjalankan tugas pertanggung jawaban suatu badan. Menurut Standar Akuntansi Keuangan maksud Iaporan keuangan adalah menyajikan fakta yang melibatkan letak keuangan dan kemampuan dengan transisi posisi keuangan pada lembaga yang berguna bagi beberapa banyak pengguna dalam pemungutan ketentuan ekonomi oleh Na'im dan Rakhman (2000:70).

Adapun uraian yang telah dijelaskan, maka dapat disimpulkan rumusan masalah pada penelitian ini berikut ini:

1. Apakah ada pengaruh Likuiditas terhadap kelengkapan pengungkapan laporan keuangan?

2. Apakah ada pengaruh Leverage terhadap kelengkapan pengungkapan laporan keuangan?

3. Apakah ada pengaruh Profitabilitas terhadap kelengkapan pengungkapan laporan keuangan?

4. Apakah ada pengaruh Ukuran Perusahaan terhadap kelengkapan pengungkapan laporan keuangan?

5. Apakah Likuiditas, Leverage, Profitabilitas, dan Ukuran Perusahaan memiliki pengaruh terhadap kelengkapan pengungkapan laporan keuangan?

\section{TUJUAN PENELITIAN}

Berdasarkan tujuan yang ingin dicapai dari penelitian ini ialah:

1. Untuk mengetahui dan menganalisis Likuiditas terhadap kelengkapan pengungkapan laporan keuangan.

2. Untuk mengetahui dan menganalisis Leverage terhadap kelengkapan pengungkapan laporan keuangan. 
3. Untuk mengetahui dan menganalisis Profitabilitas kelengkapan pengungkapan laporan keuangan.

4. Untuk mengetahui dan menganalisis Ukuran Perusahaan terhadap kelengkapan pengungkapan laporan keuangan.

5. Untuk mengetahui dan menganalisis Likuiditas, Leverage, Profitabilitas dan Ukuran Perusahaan berpengaruh secara silmutan terhadap kelengkapan pengungkapan laporan keuangan.

\section{TELAAH PUSTAKA}

1. Likuiditas

digunakan untuk menghitung kapasitas suatu badan usaha saat akan melunasi keharusan jangka pendek atau pinjaman yang hendak habis batas waktu pada saat diminta menurut keutuhan.

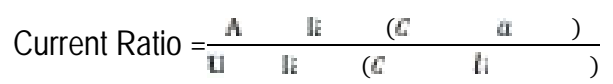

\section{Leverage}

berfungsi untuk memperkirakan berapa banyak asset perusahaan ditanggung oleh tunggakan. Jika perusahaan mempunyai nilai leverage tinggi maka institusi tersebut beresiko memenuhi pinjaman yang tinggi.

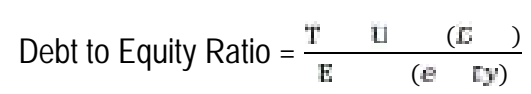

3. Profitabilitas

Kesanggupan perusahaan mencapai laba dengan menempuh semua kinerja dengan sumber daya yang dimiliki atas aktiva yang dipergunakan.

$$
\mathrm{ROA}=\frac{E \quad A \quad T \quad(E)}{T A}
$$

\section{Ukuran Perusahaan}

menunjukan kuantitas total aktiva suatu badan usaha dan bentuk kepemilikan yang dimilikinya.

\section{HIPOTESIS PENELITIAN}

$$
\text { Ukuran Perusahaan }=\text { Ln Total Aset }
$$

$\mathrm{H} 1$ = Likuiditas diduga bermakna terhadap kelengkapan pengungkapan laporan. 
H2 = Leverage diduga bermakna signifikan terhadap kelengkapan pengungkapan laporan.

H3 = Profitabilitas diduga bermakna signifikan terhadap kelengkapan pengungkapan laporan.

H4 = Ukuran perusahaan diduga bermakna signifikan terhadap kelengkapan pengungkapan laporan.

H5 = Likuiditas, leverage, profitabiiitas dan ukuran perusahaan diduga bermakna signifikan terhadap kelengkapan pengungkapan laporan.

\section{METODE PENELITIAN}

\section{POPULASI DAN SAMPEL}

Di dalam observasi ini terdapat populasi yang digunakan ialah perusahaan rokok yang terdaftar di bursa efek Indonesia

Untuk langkah pengambilan sampel menggunakan teknik purposive sampling. Kriteria yang dijadikan sebagai sampel dalam penelitian ini :

1. Perusahaan rokok yang tercatat di BEl tahun 2012-2018.

2. Melakukan publikasi laporan keuangan dan catatan atas ulasan keuangan secara berurutan di BEl selama rentang waktu 2012-2018.

3. Memperoleh laba selama periode 2012-2018.

4. Menyajikan laporan keuangan menggunakan mata uang rupiah.

\section{VARIABEL PENELITIAN}

Terdapat didalam pengkajian tersebut ada 4 variabel:

1. Plastis lepas (Independent Variabel)

Bermakna pada penyelidikan ini yang menjadi plastis terbuka yaitu likuiditas $\left(X_{1}\right)$, leverage $\left(X_{2}\right)$, profitabilitas $\left(X_{3}\right)$ dan ukuran perusahaan $\left(X_{4}\right)$ pada industri rokok yang tercantum di bursa efek Indonesia

2. $\quad$ Elastis terpikat (Dependent Variabel)

Untuk variabel terikat yang terdapat pada telaah eksperimen tersebut yakni kelengkapan pengungkapan laporan keuangan $(\mathrm{Y})$

\section{TEKNIS ANALISIS DATA}

Data yang akan di analisis pada penelitian ini berhubungan dengan variabel dependent dan variabel independen. Kaidah untuk observasi ini ialah metode analisis regresi linier berganda. Dan untuk mempermudah peneliti dalam menganalisis data yaitu menggunakan program SPSS

Dengan pengujuan dirumuskan sebagai berikut :

\section{Rumus perumpamaan bentuk regresi}




$$
Y=a+b 1 \times 1+b 2 \times 2+b 3 \times 3+e
$$

Dimana :

Y

a $\quad=$ Konstant

$\mathrm{b} 1, \mathrm{~b} 2, \mathrm{~b} 3=$ Kofisien

X1 $=$ Rasio Profitabilitas

X2 $\quad=$ Debt to Equity Ratio

X3 = Rasio Likuiditas

e $\quad=$ error term (tingkat kesalahan dalam penelitian)

\section{Rumus uji hipotesis $F$}

$$
\mathrm{t}_{\text {hit }}=\frac{r \sqrt{11-1}}{\sqrt{1}-t^{2}}
$$

Keterangan:

$\mathrm{t} \quad=$ Uji koefisien korelasi

$r \quad=$ Koefisien korelasi

$\mathrm{n} \quad=$ Jumlah sampel

\section{Rumus uji hipotesis $t$}

$$
\mathrm{F}_{\text {hit }}=\frac{R^{2} /(K-1)}{\left(1-R^{2}\right) /(n-K)}
$$

Keterangan :

$\mathrm{R} \quad=$ Koefisien korelasi ganda

$\mathrm{K}=$ Jumlah variabel bebas

\section{HASIL UJI STASTISTIK DAN PEMBAHASAN}

\section{Estimasti Regresi Linier Berganda}

Estimasi model ini digunakan untuk menjumlah kapabilitas dalam menjelaskan dan mengetahui hasil yang menguatkan dalam menyampaikan nilai suatu variabel terikat dan nilai 4 (empat) atau lebih variabel bebas.

Tabel 1.1

Hasil Uji Regresi Linier Berganda 


\begin{tabular}{cc}
\hline Variabel & $\begin{array}{c}\text { Koefisien } \\
\text { Regresi }\end{array}$ \\
\hline Konstanta & 12.009 \\
Likuiditas $(\mathrm{X} 1)$ & .465 \\
Leverage $(\mathrm{X} 2)$ & 2.180 \\
Profitabilitas $(\mathrm{X} 3)$ & 5.302 \\
Ukuran Perusahaan & 8.180 \\
$(\mathrm{X} 4)$ & \\
\hline
\end{tabular}

Berikut adalah model yang diminta :

$$
Y=12,009+0,465 X 1+2,180 \times 2+5,302 X 3+8,180 \times 4
$$

Dari hasil persamaan tersebut diatas, maka dapat diartikan bahwa :

1. Nilai konstant adalah 12,009 . Hal ini berarti bahwa tanpa adanya pengaruh variabel bebas yaitu Likuiditas, Leverage, Profitabilitas dan Ukuran Perusahaan maka nilai variabel terikat yaitu Kelengkapan Laporan Keuangan tetap konstan sebanyak 12,009 satuan

2. Diperoleh hasil dari Likuditas sebanyak 0,465 . Artinya bahwa setiap naik 1 satuan variabel Likuditas, akan mengakibatkan penurunan variable Kelengkapan Laporan Keuangan sebanyak 0,465 satuan dengan prediksi bahwa faktor lainnya adalah tetap.

3. Diperoleh hasil dari dari Leverage sebanyak 2,180. Artinya bahwa setiap kenaikan satu satuan variabel Leverage, akan mengakibatkan penurunan variable Kelengkapan Laporan Keuangan sebanyak 2,180 satuan dengan prediksi bahwa faktor lainnya tetap.

4. Diperoleh hasil dari Profitabilitas sebanyak 5,302. Artinya bahwa setiap kenaikan satu satuan variabel Profitabilitas, akan mengakibatkan penurunan variable Kelengkapan Laporan Keuangan 5,302 satuan dengan prediksi bahwa faktor lainnya tetap.

5. Diperoleh hasil dari Ukuran Perusahaan sebanyak 8,180. Artinya bahwa setiap kenaikan satu satuan variabel Ukuran Perusahaan, akan mengakibatkan penurunan variable Kelengkapan Laporan Keuangan sebanyak 8,180 satuan dengan perkiraan bahwa faktor lainnya adalah tetap.

\section{UJI F (Uji Simultan)}

Memahami akibat 4 variabel sebagai sinkron tentang variabel tergantung, dengan hasil output uji F sebagai berikut: 
Tabel 1.3

Hasil Uji F (Uji Simultan)

\begin{tabular}{cccc}
\hline Variabel & Fhit & Sig & Ket \\
\hline Likuiditas (X1) & & & Sig \\
Leverage (X2) & 39.520 & .000 & Sig \\
Profitabilitas (X3) & & & Sig \\
Ukuran Perusahaan (X4) & & & Sig \\
\hline
\end{tabular}

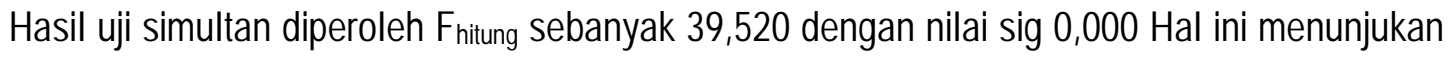
bahwa variabel likuiditas, leverage profitabilitas dan ukuran perusahaan berpengaruh secara simultan atau serentak kepada variabel kelengkapan pengungkapan laporan keuangan

\section{UJI t (Uji Parsial)}

Percobaan ini bakal mendapati apakah variabel bebas mempunyai efek sendiri-sendiri atau parsial terhadap variabel terikat. Untuk menguji hipotesis dilakukan dengan cara membandingkan nilai $t_{\text {hitung }}$ dengan nilai $t_{\text {tabel. }}$ Berikut adalah output uji $t$

Tabel 1.3

Hasil Uji t (Uji Parsial)

\begin{tabular}{cccc}
\hline Variabel & thit $_{\text {non }}$ & Sig & Ket \\
\hline Konstanta & 12.00 & .000 & Tidak \\
Likuiditas (X1) & 9 & & Sig \\
Leverage (X2) & .465 & .646 & Sig \\
Profitabilitas (X3) & 2.180 & .040 & Sig \\
Ukuran Perusahaan (X4) & 5.302 & .000 & Sig \\
\hline
\end{tabular}

Hasil uji parsial diperoleh thitung variabel likuiditas $\left(X_{1}\right)$ sebanyak 0,646 Hal ini menunjukan bahwa terdapat hipotesis yang diujikan tidak diterima. Yang berarti bahwa likuiditas tidak mempengaruhi kepada kelengkapan pengungkapan laporan keuangan

Pengaruh likuiditas terhadap kelengkapan pengungkapan laporan keuangan mempunyai nilai negatif, yang artinya setiap peningkatan likuiditas akan meningkatkan kelengkapan pengungkapan laporan keuangan semakin besar nilai kelengkapan pengungkapan laporan. Penelitian diatas sejalan dengan yang pernah dilakukan oleh Indrayani dan Chairi (2014). 
Hasil pengujian hipotesis dengan uji parsial diperoleh thitung variabel leverage $\left(X_{2}\right)$ senilai 0,040 Hal ini menyatakan bahwa tampak hipotesis yang diujikan diterima. Yang berarti bahwa leverage berdampak pada kelengkapan pengungkapan laporan keuangan. berimpak leverage kepada kepadanan pengungkapan laporan keuangan mempunyai nilai positif, yang artinya setiap peningkatan leverage akan meningkatkan kelengkapan pengungkapan laporan keuangan semakin besar nilai kelengkapan pengungkapan laporan.

Penelitian tersebut sejalan dengan yang pernah dilakukan oleh Indrayani dan Chairi (2014) Melakukan penelitian dengan judul "Pengaruh Profitabilitas, Leverage, dan Likuiditas Terhadap Kelengkapan Pengunngkapan Sukarela Dalam Laporan Tahunan pada tahun 2010-2012" dimana hasilnya membuktikan bahwa leverage berakibat pada kelengkapan pengungkapan laporan keuangan.

Hasil pengujian spekulasi dengan uji-t diperoleh thitung variabel profitabilitas $\left(X_{3}\right)$ sebanyak 0,000 Hal ini menunjukan bahwa terdapat hipotesis yang diujikan diterima. Yang berarti bahwa profitabilitas mempengaruhi kepada kelengkapan pengungkapan laporan keuangan. Pengaruh profitabilitas kepada kelengkapan pengungkapan laporan keuangan mempunyai nilai plus, yang artinya setiap naik profitabilitas akan meningkat kelengkapan pengungkapan laporan keuangan semakin besar nilai kelengkapan pengungkapan laporan. Penelitian diatas sejalan dengan yang pernah dilakukan oleh Yulianti (2012).

Hasil pengujian hipotesis dengan uji parsial diperoleh thitung variabel ukuran perusahaan $\left(X_{4}\right)$ sebanyak 0,000 Hal ini menunjukan bahwa terdapat hipotesis yang diujikan gagal ditolak. Yang bermakna bahwa ukuran perusahaan berpengaruh kepada kelengkapan pengungkapan laporan keuangan. Pengaruh ukuran perusahaan kepada kelengkapan pengungkapan laporan keuangan mempunyai nilai positif, yang artinya setiap peningkatan ukuran perusahaan akan meningkatkan kelengkapan pengungkapan laporan keuangan semakin besar nilai kelengkapan pengungkapan laporan. Penelitian diatas sejalan dengan yang pernah dilakukan oleh Daniel (2013)

\section{SIMPULAN}

Dari hasil uji asumsi atau penelitian yang telah dilakukan memperlihatkan bahwa variabel leverage $\left(X_{2}\right)$, profitabilitas $\left(X_{3}\right)$ dan ukuran perusahaan $\left(X_{4}\right)$ berimbas secara signifikan kepada kelengkapan laporan keuangan $(Y)$., uji observasi ini sejalan dengan Indrayani dan Chariri (2014) dan hasil uji hipotesis likuiditas (X1), diperoleh tidak berpengaruh atau ditolak terhadap kelengkapan laporan keuangan (Y) ini sama seperti pengamatan Indrayani dan Chariri (2014)

Sedangkan secara simultan variabel likuditas, leverage, profitabilitas dan ukuruan perusahaan berdampak signifikan kepada kelengkapan pengungkapan laporan keuangan 


\section{SARAN}

Dalam suatu penelitian diharapkan membagikan manfaat pada instansi yang bersangkutan maupun penelitian berikutnya, maka dalam penelitian ini diharapkan :

1. Bagi perusahaan

diharapkan bisa meningkatkan kelengkapan pengungkapan informasi perusahaan sehingga sanggup memberikan keterangan yang luas untuk investor.

2. Bagi Investor dapat dijadikan informasi dalam mencari perusahaan yang memiliki kondisi perusahaan dari segi kinerja keuangan yang baik agar para investor tidak salah pilih perusahaan untuk menginvestasikan dana mereka.

3. Bagi Peneliti Selanjutnya

a. Untuk penelitian selanjutnya diharapkan dapat menambah variabel-variabel lain serta dengan alat ukur kinerja keuangan lainnya yang mempengaruhi kelengkapan pengungkapan laporan keuangan

b. Penelitian ini memiliki keterbatasan dalam penggunaan sampel hanya pada perusahaan perbankan. Penelitian selanjutnya diharapkan dapat menggunakan sampel yang lebih luas ataupun sector lain yang lebih spesifik berbeda dalam aktivitasnya.

\section{DAFTAR PUSTAKA}

Daniel. 2013. Pengaruh Ukuran Perusahaan, Leverage, dan Likuiditas Terhadap Luas Pengungkapan Laporan Keuangan (Studi Pada perusahaan manufaktur yang terdaftar di BEI tahun 2008-2010) Skripsi 2014

Indrayani dan Chariri. 2014. Pengaruh Profitabilitas, Leverage, dan Likuiditas Terhadap Kelelngkapan Pengungkapan Sukarela Dalam Laporan Tahunan pada tahun 2010-2012 (Studi Pada Perusahaan Manufakturr Yang Terdaftar Di BEI Tahun 2010-2012) Skripsi 2014

Naim, Ainun dan Fuad Rachman, 2000, "Analisis Hubungan antara Kelengkapan Pengungkapan Laporan Keuangan dengan Struktur Modal dan Tipe Kepemilikan Perusahaan. Jurnal Ekonomi dan Bisnis Indonesia Vol 15.No 1.pp.70-82.

Yulianti. 2012. Pengaruh Struktur Modal, Tipe Kepemilikan, Ukuran Perusahaan, dan Profitabilitas dengan Kelengkapan Pengungkapan Laporan Keuangan (Studi Pada Perbankan Milik Swasta Yang Terdaftar Di BEI Pada Periode 2012-2016) Skripsi 2014 